6. Постановление Пленума Верховного Суда РФ от 26.12.2017 N 58 "О применении судами законодательства об обязательном страховании гражданской ответственности владельцев транспортных средств" // Бюллетень Верховного Суда РФ. № 4, апрель, 2018.

7. Постановление Девятого арбитражного апелляционного суда от 14.06.2019 N 09АП-23153/2019 по делу N A40-279289/2018 [Электронный pecypc], URL: https:/kad.arbitr.ru/ (дата обращения 11.05.2021).

8. Решение по делу №12-185/2019 Ленинского районного суда г. Чебоксары от 11 марта 2019 года. [Электронный ресурc], URL: https://bsr.sudrf.ru/bigs/portal.html (дата обращения 11.05.2021).

9. Решение по делу №12-556/2017 Центрального районного суда г. Новосибирска от 30 ноября 2017 года. [Электронный ресурc], URL: https://bsr.sudrf.ru/bigs/portal.html (дата обращения 11.05.2021).

10. Федеральный закон от 25.04.2002 № 40-Ф3 (ред. от 08.12.2020) "Об обязательном страховании гражданской ответственности владельцев транспортных средств" // Собрание законодательства РФ. 2002. № 18. Ст. 1720.

11. Информация портала ГАС «Правосудие». [Электронный ресурc], URL: https://bsr.sudrf.ru/bigs/portal.html (дата обращения 11.05.2021).

12. Пояснительная записка проекта Федерального закона N 596465-7 "О внесении изменений в статью 15.34.1 Кодекса Российской Федерации об административных правонарушениях (в части увеличения меры ответственности за необоснованный отказ от заключения публичного договора страхования либо навязывание дополнительных услуг при заключении договора обязательного страхования)" (ред., внесенная в ГД ФС РФ, текст по состоянию на 28.11.2018). [Электронный pecypc], URL: http://asozd2.duma.gov.ru/main.nsf/(Spravka)?OpenAgent\&RN=596465-7 (дата обращения 11.05.2021).

13. Текущее состояние страхового рынка в Российской Федерации в сегменте вмененного страхования. 2021. [Электронный росква. https://cbr.ru/Content/Document/File/118732/report_insurance_20210219.pdf (дата обращения 11.05.2021).

\title{
Крюков А.В.
}

\section{Уголовно-правовые и социальные аспекты молодежного экстремизма}

Санкт-Петербургский университет МВД России (Россия, Санкт-Петербург)

doi: $10.18411 / \mathrm{lj}-06-2021-219$

\section{Аннотация}

В данной статье предпринята попытка рассмотрения социальнопсихологических и уголовно-правовых аспектов возниковения молодежного экстремизма, как сложного социального феномена, включающего в себя различные формы проявления радикализма. Актуальность проблемы отражает количество вынесенных в 2020 году обвинительных приговоров за экстремистские высказывания и призывы. В статье определены современные проблемы ведущие молодежь к участию в экстремистских организациях и предложены меры противодействия экстремизму с точки зрения автора статьи.

Ключевые слова: Молодежный экстремизм, радикализм, агрессия, «социальная скука», межнациональная вражда, патриотическое воспитание.

\section{Abstract}

This article attempts to consider the socio-psychological and criminal-legal aspects of the emergence of youth extremism as a complex social phenomenon that includes various forms of radicalism. The urgency of the problem reflects the number of convictions issued in 2020 for extremist statements and appeals. The article identifies modern problems that lead young people to participate in extremist organizations and suggests measures to counter extremism from the point of view of the author of the article.

Keywords: Youth extremism, radicalism, aggression, "social boredom", interethnic hostility, patriotic education. 
Экстремизм является сложным социальным феноменом. Включает в себя самые разные формы проявления радикализма, что характеризуется приверженностью его к крайним взглядам и действиям. Как правило, экстремизм возникает там, где наличествуют излишнее возбуждение, переизбыток чувств, дефицит либо полное отсутствие эмоций. Система взглядов и действий в данном случае базируется на таких нормах, ценностях, установках, которые оправдывают уничтожение существующей целостности и идентичности. Характерной чертой экстремизма является явное насилие и агрессия, те состояния человеческого сознания, которые трактуются в психологии, как крайние. Источниками агрессии могут быть любые внешние факторы, которые оказывают влияние на человека, подталкивают его к деструктивным действиям.

Наличие набора сложных социальных явлений социально-психологического характера, таких как:

- социальные стереотипы и предубеждения,

- конформизм,

- потребность индивида в идентичности,

- депрессивные состояния и инфантильность, формируют систему мировоззренческих установок личности.

Благотворной почвой для экстремизма являются различные противоречия (антиномии) развития современного общества. Он является неотъемлемой частью социального бытия, направленного внутрь социальной структуры. Экстремизм - это форма отчуждения от общепринятых норм и ценностей.

Становлению экстремизма способствуют различные антиномии существования и развития общества: в индустриальных и постиндустриальных сообществах либерального типа, он выступает неотьемлемой частью социального бытия, поэтому правомерно говорить об экстремизме внутреннего характера (направленного в глубь социальной структуры), являющегося особой формой отчуждения от общепринятых норм и ценностей. Руководящими идеями для развития экстремизма служат:

1) состояние «социальной скуки»;

2) невозможность реализовать потребность индивида в творчестве;

3) непрерывно прогрессирующий процесс информатизации;

4) отчуждение, охватывающее сферы жизнедеятельности. Стоит уточнить что имеет ввиду автор, упоминая такое понятие как «отчуждение» применительно к формированию экстремизма. «Отчуждение-это социальный феномен, являющийся элементом (частью) цивилизационного развития, который связан с проблемой человеческого существования и рассматривается во взаимосвязи с человеческой деятельностью. Процесс отчуждения приводит к разрыву традиционных общественных связей, к утрате духовной целостности общества, к трансформации ценностных установок, что создаёт благоприятную почву для проявления деструктивности, из чего следует, что отчуждение выступает «детерминантой деструктивных проявлений» [1. С. 162].

Таким образом, можно утверждать, что целый ряд факторов влияет на формирование экстремизма. В их числе, можно назвать: дифференциацию общества, частную собственность, информацию, приводящую к деформации ценностей, моральных принципов, семью и ближайшее окружение, действие массовой культуры, нравственно-психологические характеристики личности, отношение к общепринятым нормам, к криминальным, экстремистским и террористическим группировкам.

В то же время особую тревогу вызывает молодежный экстремизм. Молодежь является самой благодатной почвой для культивации различных радикальных идеологий. Основными причинами такого положения является отсутствие своего собственного жизненного опыта и морально-нравственных ориентиров, не сформировано отношение к такому понятию как «патриотизм». В этой связи можно 
привести актуальные примеры судебной практики. Так в 2004 году в Санкт Петербурге прошла большая серия нападений на чернокожих студентов из стран Африки, а также на студентов из Китая, проживавших в различных вузовских общежитиях. Группы бритоголовых молодых людей останавливали студентов - иностранцев в различных уединенных местах, например в Парке Победы или в парке у станции метро «Горьковская», и, практически не вступая в разговор, избивали их, применяя, как правило, предметы, используемые в качестве оружия, - бейсбольные биты, цепи, кастеты. Когда жертва теряла сознание, нападавшие убегали. В результате данных нападений несколько студентов скончались. Был возбуждён ряд уголовных дел по статье 105 ч. 2 п. «ж» УК РФ - убийство, совершенное группой лиц по предварительному сговору или же по статье 111 ч. 4 УК РФ - умышленное причинение тяжкого вреда здоровью, повлекшее по неосторожности смерть потерпевшего. Позднее были задержаны несколько молодых людей, у которых в ходе обысков была изъята литература националистского толка, установлена причастность к данным убийствам членов националистической группы «Шульц - 88» под руководством Дмитрия Боброва.

А 17 августа 2020 года Верховным Судом Российской Федерации криминальное движение «АУЕ» было признано экстремистской организацией. Эта криминальная субкультура распространила свое влияние практически на все российские регионы. Основными субъектами этой экстремистской организации являются молодежь, обучающиеся школ и студенты. Другой пример характеризуется наличием молодежных экстремиских проявлений в фанатских движениях. В среде футбольных фанатов часто образуются опасные неформальные группировки, проявляющие экстремистские настроения, такие как проявление расизма, возбуждение межнациональной вражды и др.

По данным сайта Право.ru (https://pravo.ru/news/229940/) «в 2020 году в России вынесли 99 обвинительных приговоров за экстремистские высказывания в отношении 111 человек. В 2019-м таких приговоров было 73. Две трети приговоров вынесли по ст. 280 УК (публичные призывы к осуществлению экстремистской деятельности) - 66 от общего числа приговоров в отношении 75 осужденных. При этом в 52 делах это была единственная статья.»[2]

В настоящее время на учетах в органах внутренних дел Российской Федерации состоит свыше 450 молодежных группировок экстремистской направленности общей численностью около 20 тысяч человек. 147 группировок причисляют себя к движению «скинхеды», 72 - к футбольным фанатам, 31 к Российскому национальному единству, 18 - к реперам, 8 - к национал - большевистской партии.

В то же время важно выделить основные проблемы, с которыми сегодня вынуждена сталкиваться российская молодежь. Основной круг проблем лежит в плоскости межличностных отношений - в семье, в отношениях со сверстниками. Можно уверенно утверждать, что ведущую роль играют и такие факторы как:

1) «нездоровая» среда общения;

2) отсутствие жизненных планов

3) деформация системы индивидуальных ценностей;

4) неадекватное восприятие педагогических воздействий;

5) преобладание досуговых ориентаций над социально значимыми целями.

Молодежь в данном случае рассматривается автором, как большая социальная группа, которая имеет свои психологические и социальные особенности, которые, в свою очередь, объясняются становлением их духовного мира. «Досуг для молодёжи это основная сфера жизнедеятельности, в которой они самоутверждаются, реализуют свои амбиции и творческий потенциал, расширяют кругозор, совершенствуют коммуникативные способности, корректируют жизненные приоритеты, формируют 
ценностные предпочтения.» [3] Результаты социологического исследования проведенного автором среди курсантов 3 курса Санкт-Петербургского университета МВД России позволяют сделать вывод, что в свое свободное время молодежь чаще встречается с друзьями - 43\%, посещает социально-культурные и досуговые учреждения - 37,2\%, общается и играет в сети Интернет $-19,8 \%$.

Стоит уточнить, что молодежный экстремизм и терроризм является производным от взрослого, так же он наделен своими особенностями:

1. Молодые террористы и экстремисты менее склонны к компромиссам;

2. Молодежный экстремизм и терроризм стихиен;

3. Менее организованы;

4. Не имеют достаточного опыта для инициирования проведения своих акций.

Основным объектом экстремизма сегодня является духовная незрелость молодежи. Влияние окружающей среды имеет огромное значение для подростковоюношеского возраста в силу того, что в данный период происходит формирование свойств личности, потребностей, ценностных ориентиров, мотивации для самопознания, регулирования поведения. Существующая проблема молодежного экстремизма актуальна сейчас и на общемировом уровне. Сегодня на постоянной основе, на высшем уровне государственной власти рассматриваются вопросы национальной безопасности Российской Федерации. Стратегия противодействия экстремизму в Российской Федерации до 2025 года утверждена Указом Президента Российской Федерации от 29 мая 2020 года № 344. Развитие нормативно-правовой базы в сфере противодействия экстремизму в настоящее время является одним из приоритетных направлений законодательной деятельности в большинстве государств.

Экстремистские настроения проявляются в крайних взглядах, связанных с призывами к насилию или с насилием, в отношении личности, общества и государства. Этому есть объяснение - регулируемый государством притоком граждан из ближнего зарубежья, которые прибывают в Российскую Федерацию в поисках работы или для получения образования в нашей стране. Эти граждане - частые фигуранты в криминальных сводках органов внутренних дел Российской Федерации.

Подводя итог, автор уверен, что противодействие распространению экстремизма должно происходить при непосредственном участии самих подростков и студенчества. Недооценка феномена явления «молодежный экстремизм» может угрожать национальной безопасности нашего государства и общества.

$$
* * *
$$

1. Исаченко, Н. Н. Проблема деструктивности в современном российском обществе / Н. Н. Исаченко // Успехи соврем. науки. - 2017. - Т. 4, № 1. - С. 161-163.

2. Право.ru (https://pravo.ru/news/229940/)

3. Герасимова И. А. Досуговые предпочтения современной молодёжи: социально-культурный анализ // Вестник МГУКИ. 2014. №3 (59). URL: https://cyberleninka.ru/article/n/dosugovye-predpochteniyasovremennoy-molodyozhi-sotsialno-kulturnyy-analiz (дата обращения: 22.03.2021).

\section{Кудряцева Л.В., Дулепина О.В., Долженко Р.P. Принцип добросовестности в деятельности сельскохозяйственных товаропроизводителей}

Кубанский государственный аграрный университет им. И. Т. Трубилина (Россия, Краснодар)

doi: 10.18411/lj-06-2021-220

\section{Аннотация}

В современном гражданском праве Российской Федерации такой принцип, как принцип добросовестности, принято оценивать как один из ключевых. Это именно тот 